\title{
Research on the motivation of pharmaceutical workers in pharmacies
}

\author{
T. P. Zarichna ${ }^{\mathrm{A}, \mathrm{D}}$, T. S. Brytanova ${ }^{* C, \mathrm{D}}$, T. S. Raikova ${ }^{\mathrm{E}, \mathrm{F}}$, Ye. H. Knysh ${ }^{\mathrm{B}}$ \\ Zaporizhzhia State Medical University, Ukraine
}

A - research concept and design; B - collection and/or assembly of data; C - data analysis and interpretation; D - writing the article;

$\mathrm{E}$ - critical revision of the article; $\mathrm{F}$ - final approval of the article

The purpose of work was to study the motivating and demotivating factors of the activity of pharmaceutical staff and the conditions of increasing their work activity.

Materials and methods. The material for our research was statistically processed information that was obtained during the survey of pharmaceutical specialists of pharmacies that differ in the degree of market coverage (national-pharmaceutical organization 1 (PhO \# 1), local-pharmaceutical organization 2, 3 (PhO \# 2, \# 3)) and types (ready pharmacy drugs - PhO №1, pharmacy with manufacturing of drugs - PhO \# 2, \# 3). In the course of the study, methods of analysis, synthesis, grouping, questioning and the method of F. Herzberg were used.

Results. The factors of motivation, of activity, of pharmaceutical personnel were investigated as material stimulation, moral stimulation, measures of administrative influence, labor mood of the collective, desire to achieve respect in the collective, fear of losing work. As a result of comparing the estimates of motivation factors in pharmacies of both types, it was found that PhO \# 1 the leading factor of motivation was the working mood of the team $(\mathrm{Wij}=1)$, and in $\mathrm{PhO} \# 2$, \# 3 were the material stimulation $(\mathrm{Wij}=1)$. It was studied the factors of employee demotivation using the F. Herzberg method as direct management and control, working conditions, interpersonal relationships, wages and stability of work, internal organization policy towards the staff.

The results' calculations were showed that the most significant demotivating factors for the employees of the PhO \# 1 were the system of interpersonal relationships $(\mathrm{Wij}=1)$ and direct control $(\mathrm{Wij}=0.97)$. It has been studied the opinions of pharmaceutical workers on the creation of certain conditions in order to enhance their work. It was determined that the most significant conditions for increasing motivation in the $\mathrm{PhO} \# 1$, in terms of its employees, was to get high wages $(\mathrm{Wij}=0.98)$, stability $(\mathrm{Wij}=0.95)$, rational management requirements $(\mathrm{Wij}=0.94)$, harmonious relationships in the team $(\mathrm{Wij}=0.93)$, bonuses for quality of work $(\mathrm{Wij}=0.93)$, career growth $(\mathrm{Wij}=0.92)$ and comfortable working conditions $(\mathrm{Wij}=0.92)$.

Conclusion. Comparative analysis of motivation factors in pharmacies showed that in pharmacies of the first type the leading factor of motivation was the working mood of the team, and of the second type pharmacies - material stimulation. Also important for employees of pharmacies of general type. The study of demotivating factors showed that in pharmacies of both types, unstable interpersonal relationships had a negative effect on motivation. The analysis of conditions of increase of motivation showed that in PhO \# 1 it was important to receive high wages and its stability, and for $\mathrm{PhO}$ \# 2, \# 3 - harmonious relationships in the team, bonus system.

\section{Дослідження мотивації фармацевтичних працівників аптечних закладів}

\section{Т. П. Зарічна, Т. С. Британова, Т. С. Райкова, Є. Г Книш}

Мета роботи - вивчення факторів мотивації та демотивації в діяльності фрармацевтичного персоналу та дослідження умов підвищення його трудової активності.

Матеріали та методи. Матеріал для досліджень - статистично опрацьована інформація, котру отримали під час анкетування фармацевтичних фахівців аптечних закладів, що різняться за ступенем охоплення ринку (національні - фрармацевтична організація 1 (ФО № 1), місцеві - фармацевтичні організації № 2, 3 (ФО №2, № 3)) та за типом (аптека готових ліків - ФО № 1, аптека з виготовленням - ФО № 2, № 3). Протягом дослідження використовували методи аналізу, синтезу, групування, анкетування та метод Ф. Герцберґа.

Результати. Дослідили фактори мотивації діяльності фармацевтичного персоналу: матеріальне, моральне стимулювання, заходи адміністративного впливу, трудовий настрій колективу, бажання досягти поваги в колективі, страх втратити роботу. У результаті порівняння фракторів мотивації в аптеках обох типів встановили: в ФО № 1 провідним фактором мотивації $є$ трудовий настрій колективу (Wij = 1), а в ФО № 2 і № 3 - матеріальне стимулювання (Wij = 1). Вивчили фрактори демотивації працівників за мето-

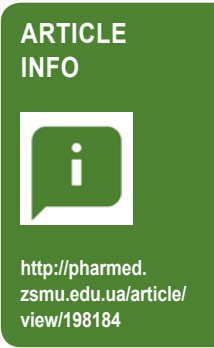

UDC 615.12:005.32]-047.37

DOI: $10.14739 / 2409-2932.2020 .1 .198184$

Current issues in pharmacy and medicine: science and practice 2020; 13 (1), 109-114

Key words: motivation, pharmacy, pharmacist.

*E-mail: goculyats@gmail.com

Received: 28.11.2019// Revised: 12.02.2019 // Accepted: 19.12.2019 
дом Ф. Герцберґа: пряме управління та контроль, умови праці, міжособистісні стосунки, заробітна платня і стабільність роботи, внутрішня політика організації щодо персоналу.

Результати показали, що найбільш значущими демотиваційними фракторами для працівників ФО № $1 €$ система міжособистісних взаємовідносин (Wij = 1) і безпосередній контроль $(\mathrm{Wij}=0,97)$. Вивчили думки фармацевтичних працівників про створення певних умов для поліпшення їхньої трудової діяльності. Визначили, що найбільш значущими умовами підвищення мотивації в ФО № 1, на думку її співробітників, є отримання високої заробітної плати $(\mathrm{Wij}=0,98)$, стабільність $(\mathrm{Wij}=0,95)$, раціональні вимоги керівництва $(\mathrm{Wij}=0,94)$, гармонічні стосунки в колективі $(\mathrm{Wij}=0,93)$, преміювання за якість праці $(\mathrm{Wij}=0,93)$, кар'єрне зростання $(\mathrm{Wij}=0,92)$ та комфортні умови праці $(\mathrm{Wij}=0,92)$.

Висновки. Порівняльний аналіз фракторів мотивації показав, що у ФО № 1 провідним фрактором мотивації є трудовий настрій колективу, а у ФО № 2 та № 3 - матеріальне стимулювання. Дослідження демотиваційних фракторів показало, що в аптеках обох типів на мотивацію негативно впливають нестабільні міжособистісні стосунки. Аналіз умов підвищення мотивації показав, що в аптеках обох типів для працівників важливе отримання високої заробітної плати та її стабільність, а у ФО № 2 та № 3 - гармонічні стосунки в колективі, система преміювання.

Ключові слова: мотивація, аптека, фармацевтичні працівники.

Актуальні питання фрармацевтичної і медичної науки та практики. 2020. Т. 13, № 1(32). С. 109-114

\section{Исследование мотивации фармацевтических работников аптечных учреждений}

\section{Т. П. Заричная, Т. С. Британова, Т. С. Райкова, Е. Г. Кныш}

Цель работы - изучение мотивирующих и демотивирующих фракторов деятельности фармацевтического персонала и исследование условий повышения его трудовой активности.

Материалы и методы. Материал для исследований - статистически обработанная инсормация, которую получили в ходе анкетирования фрармацевтических специалистов аптечных учреждений, которые отличаются по степени охвата рынка (национальные - фармацевтическая организация 1 (ФО № 1), местные - фрармацевтические организации № 2, №3 (ФО № 2, № 3)) и типу (аптека готовых лекарств - ФО № 1, аптека с изготовлением - ФО № 2, № 3). В ходе исследования использовали методы анализа, синтеза, группировки, анкетирование и метод Ф. Герцберга.

Результаты. Исследованы факторы мотивации деятельности фармацевтического персонала: материальное стимулирование, моральное стимулирование, меры административного воздействия, трудовой настрой коллектива, желание достичь уважения в коллективе, страх потерять работу. В результате сравнения оценок фракторов мотивации в аптеках обоих типов установлено: в аптеках первого типа ведущим фактором мотивации является рабочее настроение команды (Wij $=1)$, а в аптеках второго типа - материальное стимулирование. (Wij = 1). Изучены факторы демотивации работников по методу Ф. Герцберга: прямое управление и контроль, условия труда, межличностные отношения, заработная плата и стабильность работы, внутренняя политика организации в отношении персонала.

Результаты расчетов показали, что наиболее значимые демотивационные факторы для работников ФО №1 - система межличностных взаимоотношений $(\mathrm{Wij}=1)$ и непосредственный контроль (Wij = 0,97). Изучены мнения фрармацевтических работников о создании определенных условий для улучшения их трудовой деятельности. Определено, что наиболее значимыми условиями повышения мотивации в ФО № 1, с точки зрения ее сотрудников, являются получение высокой заработной платы $(\mathrm{Wij}=0,98)$, стабильность $(\mathrm{Wij}=0,95)$, рациональные требования руководства $(\mathrm{Wij}=0,94)$, гармоничные взаимоотношения в коллективе $(\mathrm{Wij}=0,93)$, премирование за качество труда $\left(\mathrm{Wij}_{\mathrm{ij}}=0,93\right)$, карьерный рост $(\mathrm{Wij}=0,92)$ и комфортные условия труда $(\mathrm{Wij}=0,92)$.

Выводы. Сравнительный анализ фракторов мотивации в аптеках показал, что в ФО № 1 ведущий фактор мотивации - трудовой настрой коллектива, а в ФО № 2 и № 3 - материальное стимулирование. Исследование демотивационных факторов показало, что в аптеках обоих типов на мотивацию негативно влияют нестабильные межличностные взаимоотношения. Анализ условий повышения мотивации показал, что для сотрудников ФО № 1 важно получение высокой заработной платы и ее стабильность, а для ФО № 2 и № 3 - гармоничные взаимоотношения в коллективе, система премирования. Для реализации мотивационной политики в аптечных учреждениях необходимо разработать модель системы мотивации персонала, которая обеспечит единство интересов учреждений и их персонала.

Ключевые слова: мотивация, аптека, фармацевтические работники.

Актуальные вопросы фармацевтической и медицинской науки и практики. 2020. Т. 13, № 1(32). С. 109-114

Motivation is closely linked to the effective work of the staff, their ability to be persistent and to overcome obstacles, to work with full dedication and enthusiasm. Undoubtedly, staff motivation is one of the most important management functions and a paramount task in the daily activities of the head of a pharmaceutical organization. It is known that the direction and nature of the employee's work behavior are based on certain motives, internal directions and personal values. In turn, the motives and interests of the individual are based on unmet needs. Thus, the better the manager understands the needs of the staff, the greater the likelihood of influencing his behavior and the ability to change it [1-7].

\section{Aim}

The purpose of the research was to study the motivating and demotivating factors of the activity of pharmaceutical staff and to study the conditions of increasing their work activity. 


\section{Materials and methods}

The material for research was statistically processed information that was obtained during the survey of pharmaceutical specialists of pharmacies that differ in the degree of market coverage (national-pharmaceutical organization 1 ( $\mathrm{PhO} \# 1$ ), local-pharmaceutical organization 2, $3(\mathrm{PhO} \# 2$, \# 3)) and types (ready pharmacy medicines $-\mathrm{PhO} \# 1$, pharmacy with manufacturing of medicines - $\mathrm{PhO} \# 2$, \#3). In the course of the study, methods of analysis, synthesis, grouping, questioning and the method of F. Herzberg were used.

\section{Results}

At the first stage, the motivation factors of pharmaceutical personnel activity were investigated: material stimulation, moral stimulation, measures of administrative influence, labor mood of the collective, desire to achieve respect in the collective, fear of losing work. These motives were proposed for evaluation by the 5-point system for pharmaceutical workers in the tested pharmacies.

The comparative characteristic of $\mathrm{PhO}$ is shown in Table 1.

To determine the relevance of individual motives to the work of the staff, the results of the motive assessment questionnaire are recalculated to the corresponding unit weight (Wij). For this purpose, the answers for each motive were summarized. The motive that has the highest rating is accepted as 1 . The significance of the remaining motives was calculated as the ratio of the sum of the responses to the parameter that received the maximum score (Tables $2,3)$.

Table 1. The comparative characteristic of pharmaceutical organization

\begin{tabular}{|c|c|c|c|}
\hline Criteria & PhO \# 1 & $\mathrm{PhO} \# 2$ & PhO \# 3 \\
\hline Market coverage & national & local & local \\
\hline Number of pharmacists and pharmaceutists & 15 & 12 & 14 \\
\hline Type of service & $\begin{array}{l}\text { Sale of medicines } \\
\text { to the population }\end{array}$ & $\begin{array}{l}\text { Sales of medicines to the population } \\
\text { and hospital departments }\end{array}$ & $\begin{array}{l}\text { Sales of medicines to the population } \\
\text { and hospital departments }\end{array}$ \\
\hline
\end{tabular}

Table 2. Evaluation of motives for work of pharmaceutical staff $\mathrm{PhO} \# 1$

\begin{tabular}{|l|l|l|}
\hline Motives for work & Rank & The specific weight of the component (Wij) \\
\hline The working mood of the team & 1 & 1.00 \\
\hline Material incentives & 2 & 0.97 \\
\hline Moral stimulation & 3 & 0.87 \\
\hline The desire to achieve respect in the team & 4 & 0.85 \\
\hline Measures of administrative impact & 5 & 0.77 \\
\hline Fear of losing your job & 6 & 0.68 \\
\hline
\end{tabular}

Table 3. Evaluation of motives for the work of pharmaceutical staff $\mathrm{PhO} \# 2$, $\mathrm{PhO} \# 3$

\begin{tabular}{|l|l|l|}
\hline Motives for work & Rank & The specific weight of the component (Wij) \\
\hline Material incentives & 1 & 1.00 \\
\hline Moral stimulation & 2 & 0.98 \\
\hline The working mood of the team & 2 & 0.98 \\
\hline Measures of administrative impact & 3 & 0.92 \\
\hline The desire to achieve respect in the team & 4 & 0.88 \\
\hline Fear of losing your job & 5 & 0.60 \\
\hline
\end{tabular}

Table 4. Estimation of factors of demotivation $\mathrm{PhO} \# 1$

\begin{tabular}{|l|l|l|}
\hline Demotivation factors & Rank & The specific weight of the component (Wij) \\
\hline Interpersonal relationships & 1 & 1.00 \\
\hline Direct management / control & 2 & 0.97 \\
\hline Internal policy of the organization towards to the staff & 3 & 0.96 \\
\hline Working conditions & 4 & 0.93 \\
\hline Salary and reliability & 4 & 0.93 \\
\hline
\end{tabular}


Table 5. Assessment of factors demotivation $\mathrm{PhO} \# 2$, \# 3

\begin{tabular}{|l|l|l|}
\hline Demotivation factors & Rank & The specific weight of the component (Wij) \\
\hline Interpersonal relationships & 1 & 1.00 \\
\hline Salary and reliability & 1 & 1.00 \\
\hline Working conditions & 2 & 0.89 \\
\hline Direct management / control & 3 & 0.87 \\
\hline Internal policy of the organization towards to the staff & 4 & 0.77 \\
\hline
\end{tabular}

\section{Earnings stability}

Reasonableness of leadership requirements

Good working conditions

Possibility of development, self-improvement

Harmonious relationships in the team

Interesting creative activity

Possibility of independence and initiative

Award for quality of work

Possibility of advanced training

Possibility of self-realization, full use of abilities

Social guarantees

\section{Career Opportunity}

Opportunity to receive high wages depending on the results of work

$\begin{array}{lllllll}0 & 0,2 & 0,4 & 0,6 & 0,8 & 1 & 1,2\end{array}$

$\mathrm{PhO} \# 2$, \# $3 \quad \square \mathrm{PhO} \# 1$

Fig. 1. Assessment of conditions for increasing the employment of pharmaceutical staff. 
At the next stage, the factors of employee motivation were studied using the F. Herzberg method: direct management and control, working conditions, interpersonal relationships, wages and stability of work, internal organization policy towards the staff (Tables 4, 5).

Important role on the system of personnel motivation is played by conditions of increasing the labor activity of pharmaceutical personnel: high and stable salary, career opportunities, social guarantees, self-realization, possibility of advanced training, optimal bonus system, possibility of displaying independence and initiative, creative activity, conflict-free conflicts in the team, the possibility of selfdeve-lopment and professional improvement, satisfactory working conditions, reasonable administration requirements.

The next step in our work was to study the opinions of pharmaceutical workers on the creation of certain conditions in order to enhance their work. The interview method was used for this purpose.

The results of this study are shown in Fig. 1.

\section{Discussion}

As a result of comparing the estimates of motivation factors in pharmacies of both types, it was found that in the first type pharmacies the leading factor of motivation is the working mood of the team $(\mathrm{Wij}=1)$, and in hospital pharmacies the material stimulation $(\mathrm{Wij}=1)$. At the same time, material incentives are also important for employees of pharmacies of general type $(\mathrm{Wij}=0.97)$. A significant factor for pharmacies of both types is moral incentive (Wij ranges from 0.87 to 0.98 ).

Administrative impact measures were more important for $\mathrm{PhO}$ \# 2, \# 3 staff $(\mathrm{Wij}=0.92)$ than for pharmacy staff $\mathrm{PhO}$ \# $1(\mathrm{Wij}=0.77)$.

It should be noted that factors such as the desire to achieve respect in the team and the fear of losing work slightly affect the work activity in both types of pharmacies (Wij from 0.85 to 0.87 in the first case and, accordingly, Wij from 0.60 to 0.68 in the second).

The results calculations (Tables 4 ) showed that the most significant demotivating factors for the employees of the $\mathrm{PhO}$ \# 1 were the system of interpersonal relationships $(\mathrm{Wij}=1)$ and direct control $(\mathrm{Wij}=0.97)$. That is, if the team had a bad psychological climate and the administration brutally controls the staff, then the motivation to work in the latter was significantly reduced.

Also, the internal staffing policy of the organization was important for pharmaceutical personnel $(\mathrm{Wij}=0.96)$. Employees of the $\mathrm{PhO}$ \# 1 would like to feel the attention, involvement, understanding and care of the administration.

The least important factors in demotivation were working conditions $(\mathrm{Wij}=0.93)$, wages and stability $(\mathrm{Wij}=0.93)$.

In $\mathrm{PhO} \# 2$, \# 3 (Table 5), from the perspective of pharmaceutical workers, the most demotivating factors were adverse interpersonal relationships $(\mathrm{Wij}=1)$ and wages and reliability $(\mathrm{Wij}=1)$. Unfavorable working conditions $(\mathrm{Wij}=0.89)$, direct management and control $(\mathrm{Wij}=0.87)$ also reduce the motivation of pharmaceutical workers.

A comparative analysis of the demotivating factors in pharmacies of both types showed that interpersonal relationships were important for their employees. If they were unfavorable, the motivation of pharmaceutical workers is reduced.

It should be noted that in pharmacy pharmacies an important disincentive was the size of wages and its stability, while in general type pharmacies this factor did not play an important role.

The difference in the assessment of disincentives in pharmacies of various types also relates to the internal policy of the organization in relation to staff and working conditions.

In the course of work (Fig. 1), it was determined that the most significant conditions for increasing motivation PhO №1, in terms of its employees, was to get high wages $(\mathrm{Wij}=0.98)$, stability $(\mathrm{Wij}=0.95)$, rational management requirements $(\mathrm{Wij}=0.94)$, harmonious relationships in the team $(\mathrm{Wij}=0.93)$, bonuses for quality of work $(\mathrm{Wij}=0.93)$, career growth $(\mathrm{Wij}=0.92)$ and comfortable working conditions $(\mathrm{Wij}=0.92)$.

Less important are self-realization $(\mathrm{Wij}=0.86)$, the possibility of development and self-improvement (Wij $=0.86)$, interesting creative activity $(\mathrm{Wij}=0.80)$, the possibility of independence and initiative $(\mathrm{Wij}=0.78)$, social guarantees $(\mathrm{Wij}=0.64)$.

Pharmaceutical employees of pharmacy pharmacies consider the most effective conditions for increasing motivation: harmonious relationships in the team $(\mathrm{Wij}=1.0)$, bonus system $(\mathrm{Wij}=1.0)$, advanced training $(\mathrm{Wij}=0.98)$, rational requirements of administration $(\mathrm{Wij}=0.96)$, receiving high wages $(\mathrm{Wij}=0.93)$, social guarantees $(\mathrm{Wij}=0.92)$, comfortable working conditions $(\mathrm{Wij}=0.92)$, and wage stability $(\mathrm{Wij}=0.92)$.

Less important for these employees were the possibility of independence and initiative $(\mathrm{Wij}=0.85)$, interesting creative activities $(\mathrm{Wij}=0.84)$ and career growth $(\mathrm{Wij}=0.82)$.

It should be noted that the opinions of pharmaceutical workers of these types of pharmacies regarding the conditions of increasing motivation have some differences. So, if in general type pharmacies the most important are employees' salaries and their stability, rational requirements of management, harmonious relationships in the collective, then in pharmacies at the hospital in the first place: harmonious relationships in the collective, bonuses, the possibility of advanced training.

\section{Conclusions}

1. Comparative analysis of motivation factors in pharmacies showed that in pharmacies $\mathrm{PhO}$ \# 1 the leading factor of motivation was the working mood of the team ( Wij $=1)$, and $\mathrm{PhO}$ \# 2, \# 3 - material stimulation $(\mathrm{Wij}=1)$. Also important for employees $\mathrm{PhO}$ \# 1 (Wij=0.97).

2 . The study of demotivating factors showed that in pharmacies of both types, unstable interpersonal relationships $(\mathrm{Wij}=1)$ have a negative effect on motivation.

3. The analysis of conditions of increase of motivation showed that $\mathrm{PhO}$ \# 1 it was important to receive high wages 
$(\mathrm{Wij}=0.98)$ and it was stability $(\mathrm{Wij}=0.95)$, and $\mathrm{PhO} \# 2$, \#3-harmonious relationships in the team $(\mathrm{Wij}=1.0)$, bonus system $($ Wij $=1.0)$.

Prospects for further research: analysis of the interaction of factors of motivation and demotivation to improve the microclimate in pharmacies.

Conflicts of interest: authors have no conflict of interest to declare. Конфлікт інтересів: відсутній.

Information about authors:

Zarichna T. P., PhD, Associate Professor of the Department of Management and Pharmacy Economics, Medical and Pharmaceutical Law, Zaporizhzhia State Medical University, Ukraine.

Brytanova T. S. PhD, Teaching Assistant of the Department of Management and Pharmacy Economics, Medical and Pharmaceutical Law, Zaporizhzhia State Medical University, Ukraine.

Raikova T. S., PhD, Associate Professor of the Department of Clinical Pharmacy, Pharmacotherapy and MFE, Zaporizhzhia State Medical University, Ukraine.

Knysh Ye. H., Dr. hab., Professor, Head of the Department of Management and Pharmacy Economics, Medical and Pharmaceutical Law, Zaporizhzhia State Medical University, Ukraine.

Відомості про авторів:

Зарічна Т. П., канд. фарм. наук, доц. каф. управління і економіки фармації, медичного та фрармацевтичного права, Запорізький державний медичний університет, Україна.

Британова Т. С., канд. фрарм. наук, асистент каф. управління і економіки фрармації, медичного та фармацевтичного права, Запорізький державний медичний університет, Україна.

Райкова Т. С., канд. фарм. наук, доц. каф. клінічної фармації, фармакотерапії і УЕФ, Запорізький державний медичний університет, Україна.

Книш Є. Г., д-р фрарм. наук, професор, зав. каф. управління і економіки фармації, медичного і фармацевтичного права, Запорізький державний медичний університет, Україна.
Сведения об авторах:

Заричная Т. П., канд. фрарм. наук, доцент каф. управления и экономики фармации, медицинского та фармацевтического права, Запорожский государственный медицинский университет, Украина. Британова Т. С., канд. фрарм. наук, ассистен каф. управления и экономики фармации, медицинского та фармацевтического права, Запорожский государственный медицинский университет, Украина.

Райкова Т. С., канд. фарм. наук, доцент каф. клинической фрармации, фармакотерапии и УЭФ, Запорожский государственный медицинский университет, Украина.

Кныш Е. Г., д-р фарм. наук, професссор, зав. каф. управления и экономики фармации, медицинского и фармацевтического права, Запорожский государственный медицинский университет, Украина.

References

[1] Tolochko, V. M., \& Halii L. V. (2008). Motyvatsiia personalu farmatsevtychnykh orhanizatsii [Motivation of the staff of pharmaceutical organizations]. Provizor, (19), 16-19. [in Ukrainian].

[2] Oljnik, S. (2008). Teoriia ta praktyka menedzhmentu personalu [Theory and practice of management of stuff]. Kharkiv: NUA. [in Ukrainian]

[3] Lukashev, S. V., \& Yandola, K. O. (2015). Motyvatsiia pratsivnykiv farmatsevtychnoi haluzi [Motivation of employees in the pharmaceutical industry]. Upravlinnia rozvytkom, (2), 19-25. [in Ukrainian].

[4] Lebed, T. V. (2015). Udoskonalennia motyvatsiinykh mekhanizmiv $v$ systemi menedzhmentu orhanizatsii. [Perfection of motivational mechanisms in system of management of organizationS]. Molody i vchenyi - Young Scientist, (11), 65-68. [in Ukrainian].

[5] Tkachenko, N. O. (2014). Vyvchennia informatsinoho profesiinoho polia spetsialistiv farmatsii [The study of informational professional field of pharmacy specialists]. Current issues in pharmacy and medicine: science and practice, (2), 106-108. [in Ukrainian]. https://doi. org/10.14739/2409-2932.2014.2.26184

[6] Gubarev, R. V. (2014). Analiz sovremennykh teorii motivatsii i stimulirovanii truda [Analysis of modern theories of motivation and incentives]. Vestnik UGUES. Nauka. Obrazovanie. Ekonomika. Seriya: ekonomika, (1), 239-246. [in Russian].

[7] Kvasniy, L. H., Soltysik, O. O., \& Fedyshyn, V. V. (2017). Rol motyvatsii i stymuliuvannia personalu v systemi zabezpechennia rozvytku pidpryiemstva [The role of motivation and stimulation of personne in the system of providing enterprise development]. Ekonomika ta upravlinnia pidpryiemstvamy, (11), 233-237. [in Ukrainian]. 